\title{
Sucrose Accumulation Maturity Curves for CP 88-17621
}

\author{
Robert A. Gilbert, James M. Shine, Jr., Jimmy D. Miller, Ronald W. Rice, and Curtis R. Rainbolt ${ }^{2}$
}

\section{Introduction}

Sugarcane (Saccharum spp.) is harvested during a 5-month period (October to March) in south Florida. "Early maturing" cultivars milled in October or November may not have reached their peak sucrose content, but may have higher sugar per ton (SPT, lbs sucrose/ton of sugarcane biomass) than other cultivars at the onset of milling operations (Miller and James, 1977). Under current industry milling capacities, harvesting the 450,000 acres of Florida sugarcane takes roughly 5 months. Unavoidably, sugarcane plants harvested during the early harvest period have not yet achieved maximum sugar content. Consequently, sugar content for any given cultivar will change over the course of the harvest season, which can impact the profitability of the harvest. Maturity curves of SPT vs. time have been developed for sugarcane cultivars in South Africa (Bond, 1982), Louisiana (Legendre and Fanguy, 1975; Legendre, 1985; Richard et al., 1981) and Mauritius (Mamet and Galwey, 1999). Although it is known that sucrose accumulation rates vary between varieties, maturity curves for recently released "CP" sugarcane cultivars (those developed at the USDA-ARS Sugarcane Field Station in Canal Point, FL) have not been reported since 1977 (Rice, 1974; Miller and James, 1977). CP cultivars occupy $>70 \%$ of Florida sugarcane acreage, and are also economically important (Tew, 2003) in many countries including Argentina (25\% of total acreage), Belize (16\%), El Salvador (50\%), Guatemala (65\%), Honduras (47\%), Mexico (15\%), Morocco (54\%), Nicaragua (75\%), Senegal (9\%) and Venezuela (9\%). Since most sugarcane growers in Florida plant a diverse selection of cultivars, these maturity curves are needed as tools to help growers make informed choices regarding harvest scheduling decisions.

This fact sheet presents the sucrose accumulation maturity curves for different crop ages (plant cane, $1^{\text {st }}$ ratoon, and $2^{\text {nd }}$ ratoon) of CP 88-1762. CP 88-1762 harvest samples were collected at 2-week intervals at 5 locations over 4 harvest seasons in the Everglades Agricultural Area. Biomass and sugar yields were determined on all samples in order to generate SPT trends over time. A full comparison of CP 88-1762 SPT trends with 12 other CP cultivars

1. This document is SS-AGR-219, one of a series of the Agronomy Department, Florida Cooperative Extension Service, Institute of Food and Agricultural Sciences, University of Florida. Published April 2004. Reviewed March 2005. This publication is also a part of the Florida Sugarcane Handbook, an electronic publication of the Agronomy Department. For more information you may contact the editor of the Sugarcane Handbook, R. A. Gilbert (ragilbert@ifas.ufl.edu). Visit the EDIS Web Site at http://edis.ifas.ufl.edu

2. R. A. Gilbert, assistant professor, Agronomy Department, Everglades REC-Belle Glade, FL; J. M. Shine, Jr., Sugar Cane Grower's Cooperative of Florida, 1500 W. Sugar House Rd, Belle Glade, FL 33430; J. D. Miller, courtesy professor, Agronomy Department, USDA-ARS, Sugarcane Field Station, 12990 US Hwy 441, Canal Point, FL 33438; R. W. Rice, Sugar Cane Grower's Cooperative of Florida, 1500 W. Sugar House Rd, Belle Glade, FL 33430; and C. R. Rainbolt, Palm Beach County Extension, 2976 SR-15, Belle Glade, FL 33430.

The use of trade names in this publication is solely for the purpose of providing specific information. UF/IFAS does not guarantee or warranty the products named, and references to them in this publication does not signify our approval to the exclusion of other products of suitable composition.

The Institute of Food and Agricultural Sciences is an equal opportunity/affirmative action employer authorized to provide research, educational information and other services only to individuals and institutions that function without regard to race, color, sex, age, handicap, or national origin. For information on obtaining other extension publications, contact your county Cooperative Extension Service office. Florida Cooperative Extension Service/Institute of Food and Agricultural Sciences/University of Florida/Christine Taylor Waddill, Dean. 
may be found in EDIS publication SS-AGR-221

Maturity Curves and Harvest Schedule

Recommendations for CP Sugarcane Varieties

(http://edis.ifas.ufl.edu/SC069).

\section{Cultivar Description}

CP 88-1762 is grown on $6.2 \%$ of the EAA sugarcane acreage (Glaz and Gilbert, 2003). This clone has a large stalk and high sugar content with good tillering ability. Descriptive information and photographs of CP 88-1762 can be found at http://edis.ifas.ufl.edu/AG136.

\section{Maturity Curves}

Figure 1 presents the sugar per ton (SPT, lbs sugar/ton sugarcane biomass) for CP 88-1762 from mid-October to mid-March. Separate curves are presented for plant cane, $1^{\text {st }}$ ratoon, $2^{\text {nd }}$ ratoon, and the entire data set.

Research has shown that older ratoon crops generally have higher SPT values but lower tonnage (Glaz et al., 1989; MacColl, 1976). Thus, growers should generally expect the SPT of their sugarcane crop to increase with crop age (see Figure 1). The mean SPT of CP 88-1762 increased from $258 \mathrm{lbs} / \mathrm{ton}$ in plant cane to $266 \mathrm{lbs} / \mathrm{ton}$ in $1^{\text {st }}$ ratoon, and 275 $\mathrm{lbs} / \mathrm{ton}$ in $2^{\text {nd }}$ ratoon. The overall mean across crop ages ranked 4 th out of $13 \mathrm{CP}$ cultivars.

Grower recommendations are based on the entire data set across all crop ages. Early-season predicted SPT for CP 88-1762 at the onset of harvest on Oct. 14 was $215 \mathrm{lbs} /$ ton (ranked 3rd out of 13 cultivars), and maximum predicted SPT was $282 \mathrm{lbs} /$ ton on Jan. 26 (ranked 5th out of 13 cultivars). In comparison to other CP cultivars, CP 88-1762 matures quickly and also deteriorates quickly following freeze events, and thus should be harvested during the first 50 days of the harvest season (see http://edis.ifas.ufl.edu/SC069).

\section{References}

Bond, R.S. 1982. Maturity differences between varieties in the selection programme. Proc. Ann. Cong. S. African Sugar Technol. Assoc. 56:136-139.
Gilbert, R.A., J.M. Shine, Jr., J.D. Miller and R.W. Rice. 2004. Sucrose accumulation and harvest schedule recommendations for $\mathrm{CP}$ sugarcane varieties. University of Florida Cooperative Extension Service Fact Sheet SS-AGR-221. University of Florida, UF/IFAS Extension Digital Information Source (EDIS) Database. http://edis.ifas.ufl.edu/SC069.

Glaz, B. and R.A. Gilbert. 2003. Sugarcane Variety Census: Florida 2001. University of Florida Cooperative Extension Service Fact Sheet SS-AGR-198. University of Florida, UF/IFAS Extension Digital Information Source (EDIS) Database. http://edis.ifas.ufl.edu/SC060.

Glaz, B., M.F. Ulloa and R. Parrado. 1989. Cultivation, cultivar and crop age effects on sugarcane. Agron. J. 81:163-167.

Legendre, B.L. 1985. Changes in juice quality of nine commercial sugarcane varieties grown in Louisiana. J. Am. Soc. Sugarcane Technol. 4:54-57.

Legendre, B.L and H. Fanguy. 1975. Relative maturity of six commercial sugarcane varieties grown in Louisiana during 1973. Sugar Bull. 53(2):6-8.

MacColl, D. 1976. Growth and sugar accumulation of sugarcane: II. Percentage of sugar in relation to pattern of growth. Expl. Agric. 12:369-377.

Mamet, L.D. and N.W. Galwey. 1999. A relationship between stalk elongation and earliness of ripening in sugarcane. Expl. Agric. 35:283-291.

Miller, J.D. and N.I. James. 1977. Maturity of six sugarcane varieties in Florida. Proc. Am. Soc. Sugar Cane Tech. 7:107-111.

Richard, C.A., F.A. Martin, and G. M. Dill. 1981. Maturity patterns of several Louisiana sugarcane varieties. J. Am. Soc. Sugarcane Technol. 8:62-65. 
Rice, E. 1974. Maturity studies of sugarcane varieties in Florida. Proc. Am. Soc. Sugarcane Technol. 4:33-35.

Schueneman, T.J., J.D. Miller, R.A. Gilbert and N.L. Harrison. 2001. Sugarcane cultivar CP 88-1762 descriptive fact sheet. University of Florida Cooperative Extension Service Fact Sheet SS-AGR-121. University of Florida, UF/IFAS Extension Digital Information Source (EDIS) Database. http://edis.ifas.ufl.edu/AG136.

Tew, T.L. 2003. World sugarcane variety census - year 2000. Sugar Cane International March/April 2003:12-18.

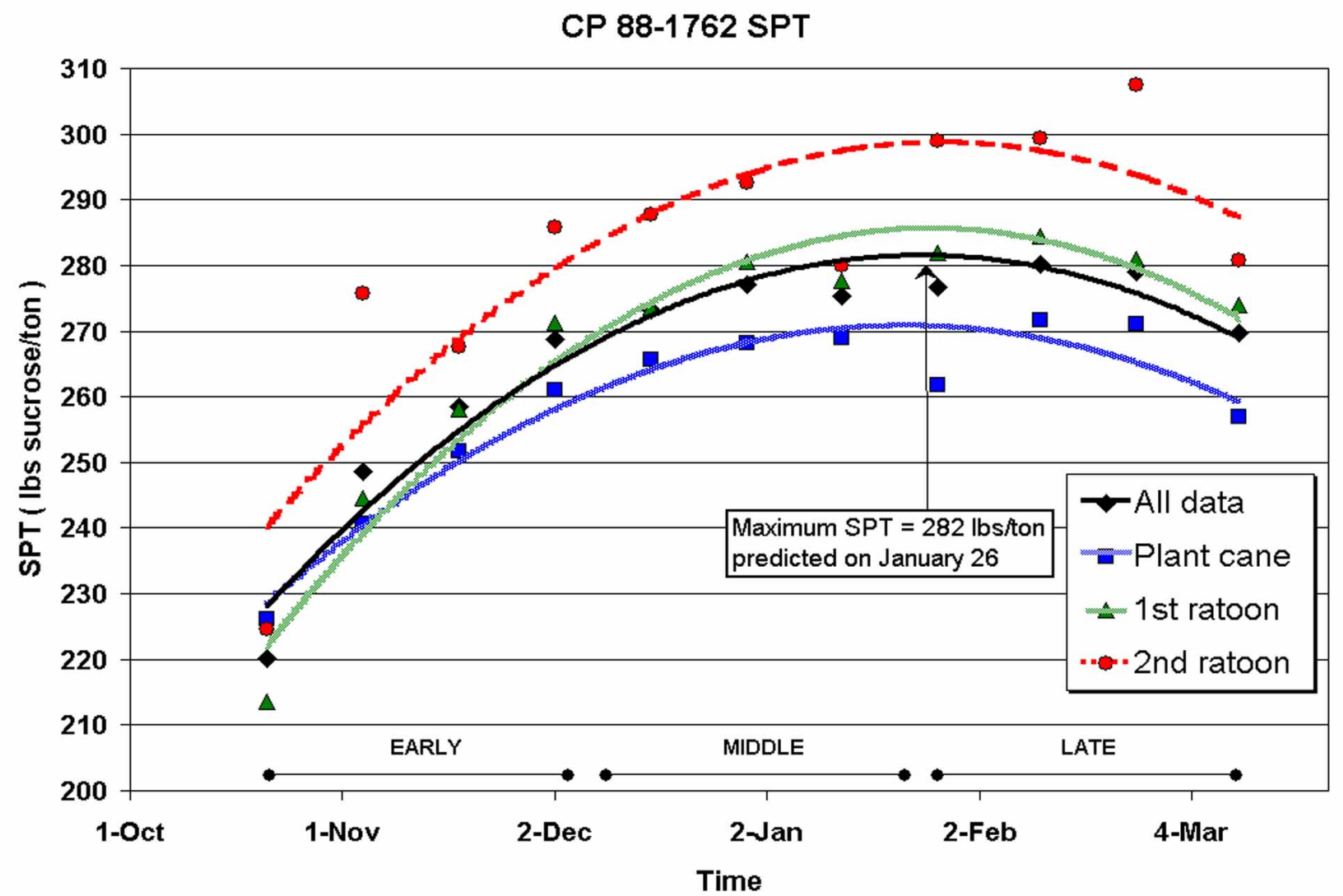

Figure 1. Sucrose Accumulation Maturity Curves for CP 88-1762. 